\title{
Economic Viability of Cassava Residues in the Nile Tilapia Diet
}

\author{
Jaomara Nascimento ${ }^{1}$, Niraldo José Ponciano ${ }^{1}$, Marcela Brite Alfaiate ${ }^{1}$, Manuel Vazquez Vidal Junior ${ }^{1}$, \\ Marize Bastos de Matos ${ }^{2}$, Geraldo Pereira Junior ${ }^{2}$, Carla Roberta Ferraz Carvalho Bila ${ }^{1}$, \\ Dalcio Ricardo de Andrade ${ }^{1}$, Geraldo de Amaral Gravina ${ }^{1} \&$ Roger Figueiredo Daher ${ }^{1}$ \\ ${ }^{1}$ State University of Northern Fluminense, Campos dos Goytacazes, RJ, Brazil \\ ${ }^{2}$ Fluminense Federal Institute, Cambuci, RJ, Brazil \\ Correspondence: Jaomara Nascimento, State University of Northern Fluminense, Campos dos Goytacazes, RJ, \\ Brasil. Tel: 22-997-194-014. E-mail: jaomarasilva@gmail.com
}

Received: July 29, 2021

doi:10.5539/jas.v13n11p118
Accepted: September 30, $2021 \quad$ Online Published: October 15, 2021

URL: https://doi.org/10.5539/jas.v13n11p118

\begin{abstract}
Fish feed represents between $50 \%$ and $70 \%$ of intensive aquaculture production costs. In this context, the present study aimed to evaluate the economic viability of the production of Nile tilapia under a diet with cassava residues in it. To evaluate the economic efficiency in relation to the inclusion of residues in the tilapia feed, the approximate cost of feed per kilogram of live weight (CMR) gained during the experimental period was determined, and later the cash flow of the production was raised for analysis of indicators: NPV (Net Present Value), CBI (Cost Benefit Rate), and IRR (Internal Rate of Return) submitted to different discount rates from existing financing sources in the region. It was found that tilapia under the diet with the inclusion of tapioca sweep in the diet, showed greater economic efficiency, and consequently higher NPV (R \$ 4,583.33), IRR (15\%) and CBR (1.17). In this sense, the viability analysis showed that cassava residues in diets of tilapia diets, indicate to be a viable strategy to better develop aquaculture production, in a more sustainable way, enhancing the technical and economic viability and minimizing the environmental impacts.
\end{abstract}

Keywords: costs, animal nutrition, Oreochromis niloticus, economic profitability

\section{Introduction}

Aquaculture is an essential agricultural practice for food security worldwide (FAO, 2016; Fore et al., 2018) and the Nile tilapia is one of the most popular species (Cai et al., 2018). In general, the pisciculture is also widely considered an option to fight hunger and poverty in developing countries (Lithgow et al., 2017).

In turn, aquaculture is a fast-growing sector with a world fish production of $80 \mathrm{MT}$ in 2016, which represents $88 \%$ of the world fish production (FAO, 2018). In this sector, the creation of tilapia is included, as the only aquaculture species with a consolidated improvement program in the country, which has contributed to the sharp increase in its production compared to other fish species (Silva et al., 2020).

Nile tilapia (Orechromis niloticus) was the most widely cultivated aquaculture species in Brazil in 2018, corresponding to $55.4 \%$ (400.3 thousand tons) of the total national fish production. From a social perspective, if practiced in a sustainable way, it can promote socioeconomic development by reducing inequalities and distributing in an equitable manner, income and assets (Costa-Pierce et al., 2010), and also in areas with natural resources abundant, can be a strategy for low-income communities to reconcile socioeconomic improvement and environmental conservation (Fonseca et al., 2017).

In Rio de Janeiro, commercial aquaculture developed from the 1980s onwards, following some sporadic incentives, but mainly driven by the private sector in search of new investment alternatives in the agricultural production sector (Scott et al., 2002). A relevant goal to keep this sector in constant growth involves the development of new researches with the objective of determining the benefits of using different feeding strategies and how these strategies influence economic and productive parameters (Gutiérrez et al., 2015; Janssen et al., 2017).

This activity has also been consolidated in Brazil as a result of available water resources, the favorable climate, relatively inexpensive labor and the growing domestic and foreign market (Garcia et al., 2013). Mostly, it has 
been practiced in semi-intensive systems, in excavated ponds with little water renewal, low or medium storage density and the use of balanced rations combined with the use of natural food (Brande, 2017).

Within this technological package, special attention should be given to the cost of food, which according to Perea-Román et al. (2018) represents $50 \%$ to $70 \%$ of the operating cost and, therefore, its change reflects a great impact on the final cost. For Nunes Souto (2015), the value of the feed should not exceed $25 \%$ of the market value of the cultivated species. This percentage can vary depending on the productivity obtained in the creation and on the value of the ingredients used in food, the latter being also greatly impacted by the cost of logistics for the purchase of these inputs in some regions.

Tilapia are organisms with protein requirements from lower food chains and eating habits that tend to be herbivores (Montoya-Camacho et al., 2018), however, intensive tilapia rearing models in close systems require protein/energy levels between 18 and $23 \mathrm{~kg} / \mathrm{MJ}$ for maintaining optimal growth in the early stages, according to Kabir et al. (2018). Another important feature to consider is that depending on the type of fish, the nutritional needs for their food will be (Boyd, 2013).

In feeding fish farming systems, fishmeal, as well as meat, blood and soy pie, are the common sources of protein used to make concentrate today (Treviño et al., 2014). The use of fish evisceration residues through silage processes, for subsequent inclusion in animal feed diets, is a high quality nutritional alternative that allows obtaining a lower cost feed, but with high production rates and feed efficiency, due to the fact that they have an appreciable nutritional composition, whose proteins are of high biological value and high digestibility, which provides great benefit in animal feed (Garcez, 2015).

Considering the high costs of these raw materials and their possible low availability in some regions, it is assumed that there is a need to seek regional alternatives of low-cost proteins with high nutritional quality in order to obtain adequate production indicators that allow improving the profitability of production units.

According to Haygood and Jha (2018), several studies on the effects of alternative feed ingredients cite economic concerns as one of the important factors to be analyzed, such as the studies carried out by Dias et al. (2020), Sabbag (2014), Carvalho et al. (2020), among others.

Thus, research on the economic viability of raising tilapia under diet with different ingredients from agro-industrial waste becomes necessary and fundamental, since the focus of fish farming is to produce high quality products at the lowest possible cost. However, there are few economic studies that use analyzes with econometric equations to obtain profitability studies in Nile tilapia, based on analyzes of economic indicators that consider monetary values over time and their attractiveness margin against others financial markets.

Among the financial economic feasibility studies used to evaluate the production of Nile tilapia, we can point out the economic analyzes of this production in a greenhouse (Gutiérrez-Leyva et al., 2020), in earthen nurseries (Trombeta et al., 2017) and in net tanks installed in lakes and reservoirs (França et al., 2016; Brabo et al., 2017), as well as in integrated production with vegetables in an aquaponic system (Quagrainie et al., 2018), in addition to application for other species in different cropping systems.

In general, these studies have shown that fish farms periodically need new investments to increase the technological level of the production system. On the other hand, existing data cannot be widely used, since the production cost reflects the use of production technology under certain environmental and economic conditions, as pointed out by Ayroza et al. (2011). Given the above, this research aimed to evaluate the economic efficiency and economic feasibility of using cassava processing residues in Nile tilapia diet.

\section{Method}

\subsection{Characterization of the Experiment}

The experiment was conducted at the Federal Institute of Education, Science and Technology Fluminense Advanced Campus Cambuci (IFF-Cambuci), in the municipality of Cambuci/RJ, in partnership with the State University of North Fluminense Darcy Ribeiro (UENF), from January to May 2017, totaling 112 days. The simulated production system is a small fish farm carried out in a nursery (excavated tank) of $1,000 \mathrm{~m}^{2}$ of water depth $(50.0 \times 20.0 \times 1.0 \mathrm{~m})$ and rearing in a single phase with a density of $3 \mathrm{fish} / \mathrm{m}^{3}$.

Three rations were manufactured to feed the fish, one with only traditional ingredients, without inclusion of cassava waste (control; T1) and two with alternative ingredients (waste obtained from agro-industries in the region): cassava peel flour $24 \%$ (T2) and tapioca dusting flour (T3). The formulations of the three diets, shown in Table 1, are isoprotein ( $36 \%$ crude protein), isocaloric $(3.100 \mathrm{Kcal})$. 
Table 1. Formulation in percentage of the ingredients of the experimental and control diets

\begin{tabular}{llll}
\hline \multirow{2}{*}{ Ingredients $(\%)$} & \multicolumn{2}{c}{ Treatments } \\
\cline { 2 - 4 } Corn meal & T1 (WAR) & T2 (ARMPF) & T3 (ARTSF) \\
Wheat bran & 19.08 & 2.00 & 1.00 \\
Soybean meal & 8.00 & 2.00 & 2.00 \\
Fish's flour & 54.92 & 38.09 & 28.00 \\
Premix & 15.00 & 30.91 & 42.00 \\
Fish oil & 2.00 & 2.00 & 2.00 \\
Residue 1 (RAFCM) & 1.00 & 1.00 & 1.00 \\
Residue 2 (RAFVT) & 0.00 & 24.00 & 0.00 \\
Total & 0.00 & 0.00 & 24.00 \\
\hline
\end{tabular}

Note. T1 (WAR): without agro-industrial residue; T2 (ARMPF): agro-industrial residue from manioc peel flour; T3 (ARTSF): agroindustrial residue from tapioca sweeping flour.

All diets were formulated with $3,100 \mathrm{Kcal} / \mathrm{Kg}$ of digestible energy and $36 \%$ crude protein.

\subsection{Economic Evaluation}

Economic aspects are important in the planning, control and decision-making of fish farming, since costs play two important roles, managerial and business. The aim is to provide data for establishing standards, budgets and other forms of forecasting and, subsequently, comparing the values already reported by other researches in different production systems.

To evaluate the economic efficiency in relation to the inclusion of residues in the feeding of tilapia, the approximate cost of feed per kilogram of live weight (AFC) gained during the experimental period was determined, as recommended by Bellaver et al. (1985). The AFC correlates the cost of the feed provided to the zootechnical performance obtained.

$$
A F C=\frac{\left(Q_{i} \times C_{i}\right)}{W G_{i}}
$$

Where, $A F C=$ average feed cost per kilogram gained in the $i$-th treatment; $Q_{i}=$ average amount of feed used in the i-th treatment; $C_{i}=$ average cost per kilogram of feed used in the i-th treatment; $G P_{i}=$ mean weight gain of the i-th treatment.

Then, the economic efficiency index (EEI) and the cost index (CI) were calculated according to Barbosa et al. (1992) from the following equations:

$$
\begin{gathered}
E E I=\frac{L C e}{A C e_{i}} \times 100 \\
C I=\frac{A C e_{i}}{L C e} \times 100
\end{gathered}
$$

Where, $E E I=$ economic efficiency index; $C I=\operatorname{cost}$ index; $L C e=$ lowest average cost observed in feed per kilogram of live weight between treatments; $A C e_{i}=$ average cost of treatment $i$ considered.

\subsection{Economic Feasibility Analysis}

Productivity was calculated based on the survival rate of the fingerlings of $93 \%$ for the entire cycle and a slaughter weight of 800 grams at the end of a 12-month rearing period. The price of whole fish paid to the producer considered was $\mathrm{R} \$ 6.00 / \mathrm{Kg}$ and the prices of inputs used to make up the cash flows were average prices obtained in the North and Northwest regions of Rio de Janeiro in 2016.

The cash flow values resulted from the inflows and outflows of resources and products throughout this period and, at the end of this investment horizon, the inputs that had not yet exhausted were recorded as revenues in this last year. In this way, the residual values of land, facilities and equipment entered as revenue at the end.

All prices used in the economic analysis, whether for sale of the product or purchase of inputs, were collected in the North Fluminense region to reflect the real economic potential of the alternatives tested. 
The prices of the ingredients of the diet were obtained in Campos dos Goytacazes/RJ, in October 2016. Such prices $(\mathrm{R} \$ / \mathrm{Kg}$ ) used in the elaboration of the costs were: corn (R\$ 1.30), wheat bran (R\$1.18), soybean meal $(\mathrm{R} \$ 2.16)$, fish meal ( $\mathrm{R} \$ 2.22)$, vitamin and mineral premix ( $\mathrm{R} \$ 13.50)$ and fish oil ( $\mathrm{R} \$ 2.00)$. Waste for reuse was considered as zero cost.

From the construction of the cash flow through the technical coefficients, the following profitability indicators were used: the Net Present Value (NPV), the Internal Rate of Return (IRR) and the Benefit-Cost Ratio (BCR), which have the fact that they consider the effect of the period of time on monetary values is an advantage.

The NPV consists of transferring to the current instant all expected cash flows, discounting them at a certain interest rate and adding them algebraically, being determined by the expression below. The NPV must be positive for the project to be accepted.

$$
N P V=-I+\sum_{j=1}^{n} \frac{C F_{t}}{(1+k)^{t}}
$$

Where, $I=$ capital investment at zero date; $F C_{t}=$ return on date $\mathrm{t}$ of the cash flow; $n=$ project analysis period $k=$ minimum rate to carry out the investment or capital cost of the investment project.

If the result is less than zero, it means that the return on investment was less than the desired minimum, so the project is considered rejected. If the result is greater than or equal to zero, the project presents an indication of feasibility (Ross et al., 2015; Assaf Neto, 2014).

$$
0=-I+\sum_{j=1}^{n} \frac{F C_{t}}{(1+I R R)^{t}}
$$

The BCR of a project is the rate that nullifies the NPV of the investment's cash flow. It is the one that makes the present value of future profits equivalent to the expenses incurred with the project, thus characterizing the rate of return on invested capital. The higher the IRR, the more solid the project will be, which must be above the minimum attractiveness rate for the project to be accepted.

The BCR consists of transferring to the current instant all expected cash flows, discounting them at a certain interest rate and dividing them by the invested capital, being determined by the expression below. The BCR must be above 1 for the project to be accepted, indicating that the capital obtained (benefit) was greater than the capital invested (cost).

$$
B C R=\sum_{j=1}^{n} \frac{C F_{j}}{(1+i)^{t}} / C F_{0}
$$

Where, $C F_{j}=$ cash flow at time $j ; i=$ interest rate; $C F_{0}=$ capital invested at the start of the project. This index analyzes the "cost/benefit" of the project and provides a measure of the expected return per monetary unit (BRAGA, 2010).

\section{Results and Discussion}

It was observed that the cost of conventional feed is higher than the cost of feed with cassava waste, having as its main justification the assumption of zero cost, that is, the reuse of cassava waste (Table 2). However, it is worth noting that the average feed cost per kilogram of live weight with tapioca dusting flour residue is lower than the cost of feed with cassava husk, thus demonstrating a better economic/zootechnical balance, since this alternative significantly achieves the ratio of high quality products at the lowest possible cost.

It is possible, therefore, to point out that the economic efficiency index generated by the treatment with tapioca dusting flour enables greater economic efficiency than the others. 
Table 2. Economic efficiency of the use of cassava processing residues in the Nile tilapia diet

\begin{tabular}{llll}
\hline \multirow{2}{*}{ Variables } & \multicolumn{3}{c}{ Treatments } \\
\cline { 2 - 4 } & T1 (SRA) & T2 (RAFCM) & T3 (RAFVT) \\
\hline Race cost $(\mathrm{R} \$ / \mathrm{Kg})$ & 2.15 & 1.85 & 1.87 \\
$\mathrm{AFC}(\mathrm{R} \$ \mathrm{Kg}$ PVG) & $7.57^{\mathrm{ab}}$ & $7.78^{\mathrm{a}}$ & $4.85^{\mathrm{b}}$ \\
Cost index & 193.27 & 198.86 & 124.03 \\
EEI & 51.74 & 50.29 & 80.63 \\
\hline
\end{tabular}

Note. T1 (WAR): without agro-industrial residue; T2 (ARMPF): agro-industrial residue from manioc peel flour; T3 (ARTSF): agroindustrial residue from tapioca sweeping flour.

abc Means followed by at least one equal letter on the same line do not differ at the $5 \%$ probability level by Tukey's test.

These data corroborate other studies that established comparisons between the sources of feed ingredients. Pereira Junior et al. (2013), observed that the use of cassava flour in different degrees of substitution to corn in the feeding of tambaqui contributed to a decrease of around $15 \%$ in the cost of feed production. As observed by Cruz et al. (2006), who identified a lower cost per kilogram of feed with the inclusion of cassava trimming flour to replace corn in feed for laying hens.

It is worth noting that although the treatments show statistically significant similarity, in terms of economic aspects, the inclusion of cassava residues in Nile tilapia farming may enable the identification of alternative sources of nutrients that are less costly at the total cost of production. In addition, the reuse of these residues as an alternative ingredient also contributes to the preservation of the environment and the sustainability of all agricultural activities.

Gutierrez-Leyva et al. (2020) explain that within the panorama of the development of new policies in world aquaculture, the application of new production models aimed at species with high commercial demand and low production costs, has clear objectives for economic development, employment and protection of the environment.

The simulation of cash flows obtained over 3 years from the use of feed was done only with traditional ingredients and alternative feed made with the inclusion of tapioca dusting flour (T3), considering that the latter presented superior zootechnical results to the diet with inclusion of cassava peel flour. Based on this observation, the production costs and the economic viability of tilapia production were comparatively analyzed with the two treatments that presented the highest economic efficiency index.

Although the revenue obtained is considered the same, considering that there is no price difference for the product offered, the lower feed cost with tapioca sweeping allows for greater NPV achievement over three years. For both conditions, the NPV $>0$ is obtained, however in the rearing of tilapia with traditional feed, NPV equivalent to $\mathrm{R} \$ 1,041.81$ was obtained, and $\mathrm{R} \$ 4,583.33$ for tilapia fed with tapioca-scanned feed (Table 3).

Table 3. Summarized cash flows of Nile tilapia production with traditional diet feed and cassava sweeping residue insertion

\begin{tabular}{|c|c|c|c|c|c|c|}
\hline & \multicolumn{3}{|c|}{ T1 (SRA) } & \multicolumn{3}{|c|}{ T3 (RAFVT) } \\
\hline & Year $1(\mathrm{R} \$)$ & Year $2(\mathrm{R} \$)$ & Year $3(\mathrm{R} \$)$ & Year $1(\mathrm{R} \$)$ & Year $2(\mathrm{R} \$)$ & Year $3(\mathrm{R} \$)$ \\
\hline Revenue & $13.392,00$ & $13.392,00$ & $13.392,00$ & $13.392,00$ & $13.392,00$ & $13.392,00$ \\
\hline Costs & $42.367,60$ & $10.587,60$ & $10.587,60$ & $41.117,68$ & $9.337,68$ & $9.337,68$ \\
\hline Cash flow & $(28.975,60)$ & $2.804,40$ & $30.754,90$ & $(27.725,68)$ & $4.054,32$ & $32.004,82$ \\
\hline NPV 6\% & $\mathrm{R} \$ 1.041,81$ & & & $\mathrm{R} \$ 4.583,33$ & & \\
\hline IRR & $7,98 \%$ & & & $15,00 \%$ & & \\
\hline BCR & 1.04 & & & 1.17 & & \\
\hline
\end{tabular}

Note. T1 (WAR): without agro-industrial residue; T3 (ARTSF): agroindustrial residue from tapioca sweeping flour. 
In western Paraná, Queiroz (2015) analyzed the economic feasibility of raising tilapia in excavated tanks, and concluded that the NPV was positive, meaning that the capital invested in the project will be recovered. And just as in this research, in addition to the financial indicators, the researcher also emphasizes that agricultural and livestock activities are exposed to climate and price variations.

Regarding the IRR, it can be considered that the closer the IRR of the business is to the minimum attractiveness rate (MAR), the more subject the activity will be to inflationary fluctuations in the economy, which can be crucial for the family producer who does not have of financial reserve to get through periods of economic recession. Based on this principle, the T3 ration is observed as promising a greater safety margin for the activity, as only interest rates above $15 \%$ would make the project unfeasible, while interest rates above $8 \%$ already make the use of the ration unfeasible. $\mathrm{T} 1$.

Rocha et al. (2020) when analyzing the economic viability of the cultivation of Nile tilapia in Rio Grande do Sul also found both the NPV and the IRR, indicating that the cultivation of tilapia will pay more than the minimum rate expected by the rural property.

Following the assumption of the benefit-cost ratio, it indicates how much profitability there will be in that period, in adjusted values, based on the investment made. Thus, for every $\mathrm{R} \$ 1.00$ invested in raising tilapia using the T3 feed, there will be a cash flow of $\mathrm{R} \$ 1.17$. In the use of $\mathrm{T} 1$ feed, this flow would be only $\mathrm{R} \$ 1.04$, about $11 \%$ lower.

It is important to pay attention to this information as indexes that demonstrate the alternatives that could contribute to cost reduction, especially in food, since this is commonly identified as the largest composition of the total cost of fish farming, according to Oliveira et al. (2014); Janssen et al. (2017).

In this context, it is worth noting that this is a sustainable activity that can take advantage of different agricultural residues, in addition to providing the fish farmer with profitability, with significant gains for the regional economy, as shown by Sabbag (2014). However, like any other economic activity, it needs a strategy or basic planning to produce good results in its production units.

Finally, it is noteworthy that these observations must be added to the possibilities of marketing and the variation in product prices (Ayroza et al., 2011), as determining factors for its good cost-benefit. Since there are both zootechnical and market factors that interfere in the productivity and profitability of tilapia farming, as pointed out by Garcia et al. (2016).

\section{Conclusion}

The highest economic profitability index was achieved with the inclusion of tapioca sweeping in the diet, which is why it is highlighted that when feeding Nile tilapia with this food, a greater economic reward is achieved per kilogram of fish meat produced. Furthermore, the use of cassava residues in tilapia diets made it possible to establish a sustainable production strategy, with a better cost-benefit rate between the reduction in food costs and the environmental impact.

\section{Acknowledgements}

We are grateful for the funding obtained by the Pescarte Environmental Education Project (PEA), which is a mitigation measure required by the federal environmental licensing, conducted by IBAMA.

\section{References}

Assaf Neto, A. (2014). Finanças corporativas e valor (7th ed.) São Paulo: Atlas.

Ayroza, L. M. S., Romagosa, E., Ayroza, D. M. M. R., Scorvo Filho, J. D., \& Salles, F. A. (2011). Custos e rentabilidade da produção de juvenis de tilápia-do-nilo em tanques-rede utilizando-se diferentes densidades de estocagem. Revista Brasileira de Zootecnia, 40(2), 231-239. https://doi.org/10.1590/S1516-35982011 000200001

Bellaver, C., Fialho, E. T., \& Protas, J. F. S. (1985). Radícula de malte na alimentação de suínos em crescimento e terminação. Pesquisa Agropecuária Brasileira, 20(8), 969-974.

Boyd, C. E. (2013). 1-Overview of aquaculture feeds: Global impacts of ingredient use. Feed and Feeding Practices in Aquaculture: Woodhead Publishing Series in Food Science, Technology and Nutrition (pp. 3-25). Elsevier, Amsterdã. https://doi.org/10.1016/B978-0-08-100506-4.00001-5

Brabo, M. F., Paixão, D. J. de M. R., Mesquita, R. L., Costa, M. W. M., Campelo, D. A. V., \& Veras, G. C. (2017). Economic feasibility of tilapia creation in net cages in Northeast of Para State, Amazon. Custos e @gronegócio Online, 13(Special Edition). 
Braga, R. (2010). Fundamentos e técnicas de administração financeira. São Paulo: Atlas.

Brande, M. R. (2017). Modelagem do crescimento corporal e análise de cenários econômicos da produção de pacu (Piaractus mesopotamicus) em sistema semi-intensivo na região do Vale do Ribeira, São Paulo (59f., Monografia (Trabalho de Conclusão de Curso), Universidade Estadual Paulista "Júlio de Mesquita Filho", São José do Rio Preto, SP).

Cai, J. N., Leung, P. S., Luo, Y. J., Yuan, X. H., \& Yuan, Y. (2018). Melhorando o desempenho da criação de tilápias sob variação climática: Perspectiva da modelagem bioeconômica. Artigo Técnico de Pesca e Aquicultura da FAO (Vol. 608, p. 64).

Costa-Pierce, B. A. (2010). Sustainable ecological aquaculture systems: The need for a new social contract for aquaculture development. Mar. Technol. Soc. J., 44, 88-112. https://doi.org/10.4031/MTSJ.44.3.3

Cruz, F. G. G., Filho, M. P., \& Chaves, F. A. L. (2006). Efeito da substituição do milho pela farinha da apara de mandioca em rações para poedeiras comerciais. Revista Brasileira de Zootecnia, 35(6), 2303-2308. https://doi.org/10.1590/S1516-35982006000800015

Dias, D. De C., Furlaneto, F. De P. B., Sussel, F. R., Tachibana, L., Gonçalves, G. S., Ishikawa, C. M., ... Ranzani-Paiva, M. J. T. (2020). Economic feasibility of probiotic use in the diet of Nile tilapia, Oreochromis niloticus, during the reproductive period. Acta Scientiarum. Animal Sciences, 42(1), e47960. https://doi.org/10.4025/actascianimsci.v42i1.47960

FAO (Food and Agriculture Organization). (2016). Organização para a Alimentação e Agricultura. Situação mundial da pesca e da aquicultura. Contribuindo para a segurança alimentar e nutricional de todos. FAO, Roma.

FAO (Food and Agriculture Organization). (2016). The State of World Fisheries and Aquaculture 2016-Contributing to food security and nutrition for all (p. 200). FAO, Rome.

FAO (Food and Agriculture Organization). (2018). The State of World Fisheries and Aquaculture 2018-Meeting the sustainable development goals. FAO, Rome.

Fonseca, T., David F. S., Ribeiro F. A. S., Wainberg A. A., Valenti, W. C. (2017). Technical and economic feasibility of integrating seahorse culture in shrimp/oyster farms. Aquaculture Research, 48, 655-664. https://doi.org/10.1111/are.12912

Fore, M., Frank, K., Norton, T., Svendsen, E., Alfredsen, J., Dempster, T., ... Berckmans, D. (2018). Precision fish farming: A new framework to improve production in aquaculture. Biosystem Engineering, 173, 176-193. https://doi.org/10.1016/j.biosystemseng.2017.10.014

França, E. D. (2016). Custos e Rentabilidade da Produção de Tilápia em Áreas não onerosas, período 2001 a 2015 (p. 67, Dissertação (Mestrado) Programa de Pós-graduação em Ciências Animal e Pastagens, Escola Superior de Agricultura "Luiz de Queiroz”, Universidade de São Paulo).

Garcés, Y. (2015). Avaliação do crescimento e uso nutricional in vivo e in vitro da silagem de subprodutos de pescado em frangos de corte (p. 160, Dissertação de Mestrado em Ciências Agrárias, Sede da Universidade Nacional da Colômbia Palmira, Escola de Pós-Graduação, Palmira, Colômbia).

Garcia, F., Romera, D. M., Gozi, K. S., Onaka, E. M., Fonseca, F. S., Schalch, S. H. C., ... Portell, M. C. (2013). Stocking density of Nile tilapia in cages placed in a hydroelectric reservoir. Aquaculture, 410, 51-56. https://doi.org/10.1016/j.aquaculture.2013.06.010

Garcia, F., Romera, D. M., Sousa, N. S., Paiva-Ramos, I., \& Onaka, E. M. (2016). The potential of periphyton-based cage culture of Nile tilapia in a Brazilian reservoir. Aquaculture, 464, 229-235. https://doi.org/10.1016/j.aquaculture.2016.06.031

Gutiérrez, R., Uriarte, I., Yany, G., \& Farías, A. (2015). Productive performance of juvenile Patagonian red octopus (Enteroctopus megalocyathus) fed with fresh preys: Are relevant the quantity of protein and energy on diets. Aquaculture Research, 46(S1), 64-75. https://doi.org/10.1111/are.12585

Gutiérrez-Leyva, R., Ulloa, J. A., Ramírez-Ramírez, J. C., Bautista-Rosales, P. U., Rosas-Ulloa, P., Silva-Carrillo, Y., ... Camarena-Herrera, M. E. (2020). Evaluation of the intensive production of juvenile tilapia under greenhouse conditions: Profitability analysis and aspects of its applicability. Revista Bio Ciências, 7, e584, https://doi.org/10.15741/revbio.07.e584

Haygood, A., \& Jha, R. (2018). Estratégias para modular a microbiota intestinal de tilápia (Oreochromis sp.) na aquicultura: uma revisão. Comentários em Aquaculture, 10(2), 320-333. https://doi.org/10.1111/raq.12162 
Janssen, K., Berentsen, P., Besson, M., \& Komen, H. (2017). Derivation of economic values for production traits in aquaculture species. Genetics Selection Evolution, 49(5), 1-13. https://doi.org/10.1186/s12711-0160278-X

Kabir, K. A., Schrama, J. W., Verreth, J. A. J., Phillips, M. J., \& Verdegem, M. C. J. (2018). Effect of dietary protein to energy ratio on performance of Nile tilapia andfood web enhancement in semi-intensive pond aquaculture. Aquaculture, 499(15), 235-242. https://doi.org/10.1016/j.aquaculture.2018.09.038

Lithgow, D., De La Lanza, G., \& Silva, R. (2017). Estratégias de gestão baseadas em ecossistemas para melhorar a aquicultura em países em desenvolvimento: Um estudo de caso de marismas nacionales. Ecological Engineering, 130, 296-305. https://doi.org/10.1016/j.ecoleng.2017.06.039

Montoya-Camacho, N., Oloño, J. T. H., Ríos, E. M., Rodríguez-Félix, F., Torres-Arreola, W., Yañez, F. J. C., ... Higuera, V. M. O. (2018). Efecto de la sustitución de proteína animal por vegetal en el alimento sobre la fisiología de la tilapia del Nilo. Biotecnia, 20(2), 37-42. https://doi.org/10.18633/biotecnia.v20i2.598

Nunes Souto, C. (2015). Farinha de camarão em dietas para tambaqui (Colossoma macropomum) (p. 72, Dissertação (Mestrado em Zootecnia), Universidade Federal de Goiás Escola de Veterinária e Zootecnia).

Oliveira, C., Ludke, M., Ludke, J., Lopes, E., Pereira, P. E., \& Cunha, G. (2014). Composição físico-química e valores energéticos de farinhas de silagem de peixe para corte. Arquivo Brasileiro de Medicina Veterinária e Zootecnia, 66(3), 933-939. https://doi.org/10.1590/1678-41626127

Perea-Román, C., Garcés-Caicedo, Y. J., Muñoz-Arboleda, L. S., Hoyos-Concha, J. L., \& Gómez-Peñaranda, J. A. (2018). Valoración económica del uso de ensilaje deresiduos piscícolas en la alimentación de Oreochromis spp. Biotecnología en el Sector Agropecuario y Agroindustrial, 16(1), 43-51. https://doi.org/ 10.18684/BSAA(16)43-51

Pereira Junior, G. P., Pereira, E. M. D. O., Pereira Filho, M., Barbosa, P. D. S., Shimoda, E., \& Brandão, L. V. (2013). Desempenho produtivo de juvenis de tambaqui (Colossoma macropomum Cuvier, 1818) alimentados com rações contendo farinha de crueira de mandioca (Manihot esculenta Crantz) em substituição ao milho (Zea mays). Acta amazônica, 43(2), 217-226. https://doi.org/10.1590/S0044-596720 13000200013

Quagrainie, K. K. Flores, R. M. V., Kim, H., \& Mcclain, V. (2017). Economic analysis of aquaponics and hydroponics production in the U.S. Midwest. Journal of Applied Aquaculture, 30(1), 1-14. https://doi.org/ 10.1080/10454438.2017.1414009

Queiroz, R. B. (2015). Estudo da viabilidade econômica da criação de tilápias em tanques escavados no Oeste Paranaense (17f., Trabalho de Conclusão de Curso (MBA em Gestão do Agronegócio), Universidade Federal do Paraná, Curitiba).

Rocha, G. D. S. R., Kuchak, M. L., Biguelini, D., Rocha, P. D., Oliveira, L., \& Lago, A. (2020). Viabilidade econômica em um sistema de produção do cultivo de tilápia: Um estudo de caso em uma propriedade rural. Nucleus, 17(1). https://doi.org/10.3738/1982.2278.3670

Ross, S. A., Westerfield, R. W., Jaffe, J., \& Lamb, R. (2015). Administração financeira: versão brasileira de corporate finance (10th ed.). Porto Alegre: AMGH.

Sánchez, O. (2016). Obtenção de farinha de silagem biológica de truta arco-íris (Oncorhynchus mykiss) esubprodutos de tilápia vermelha (Oreochromis spp.) (p. 96, Tese de Engenharia Agroindustrial, Departamento de agroindústria, Faculdade de Ciências Agrárias, Universidad del Cauca, Popayán, Colômbia).

Scott, P. C., Vianna, L. F., \& Mathias, M. A. (2002). Diagnóstico da cadeia aquícola para o desenvolvimento da atividade no Estado do Rio de Janeiro. Rio de Janeiro: SEBRAE.

Silva, A. C. F., Corrêa Filho, R. A. C., Ventura, A. S., Nunes, A. L., Laice, L. M., Ribeiro, R. P., ... Povh, J. A. (2020). Reproductive traits in different Nile tilapia genetic groups. Arquivo Brasileiro de Medicina Veterinária e Zootecnia, 72(5), 1797-1804. https://doi.org/10.1590/1678-4162-11764

Treviño, L., Abdo, M., Cruz, E., \& Ricque, D. (2014). Fatores de qualidade em farinha de peixe e em lipídios alimentares de peixe. Advances in Aquaculture Nutrition, III.

Trombeta, T. D., Bueno, G. W., \& Mattos, B. O. (2017). Análise econômica da produção de tilápia em viveiros escavados no Distrito Federal. Informações Econômicas, 47(2). 


\section{Copyrights}

Copyright for this article is retained by the author(s), with first publication rights granted to the journal.

This is an open-access article distributed under the terms and conditions of the Creative Commons Attribution license (http://creativecommons.org/licenses/by/4.0/). 